\title{
Pembelajaran Kooperatif Tipe Numbered Head Together dan Think Pair Share Ditinjau dari Motivasi
}

${ }^{1}$ Laxmi Zahara, ${ }^{2}$ Khaerus Syahidi ${ }^{2},{ }^{3}$ Fartina, ${ }^{4}$ Baiq Aryani Novianti, ${ }^{5}$ Suriani

$1,2,3,4,5$ Prodi Pendidikan Informatika, FMIPA, Universitas Hamzanwadi, Jln. TGKH Muhammad Zainuddin Abdul Madjid No. 132 Pancor, Selong, Lombok Timur, NTB 83611 Email Korenspondensi: laxmizahara3@gmail.com

\begin{tabular}{|c|c|}
\hline Article Info & bstract \\
\hline $\begin{array}{l}\text { Article History } \\
\text { Received: } 25 \text { April } 2021 \\
\text { Revised: } 20 \text { June } 2021 \\
\text { Published: } 30 \text { June } 2021\end{array}$ & \multirow{2}{*}{$\begin{array}{l}\text { This study aims to determine the effect of the NHT and TPS learning models on } \\
\text { student achievement, the effect of motivation on student achievement, and the } \\
\text { interaction between learning models and motivation on student achievement. } \\
\text { This type of research is experimental research. The population in this study } \\
\text { were all students of class VII MTs. NW Wanasaba totaling } 60 \text { people consisting } \\
\text { of } 3 \text { classes, namely: class VIIA, VIIB and VIIC. The research sample was class } \\
\text { VIIA and VIIB which was obtained by means of Cluster Random Sampling. The } \\
\text { data collection technique was carried out using multiple choice objective test } \\
\text { method. The prerequisite test used is the normality test and homogeneous test, } \\
\text { where the normality test uses the chi-square test and the homogeneity test uses } \\
\text { the Bartlet test. While the data analysis technique used to test the hypothesis is } \\
\text { the Two Way ANOVA test and the Scheff test for further ANOVA testing. The } \\
\text { results of the analysis in this study indicate that there is an influence of the } \\
\text { NHT and TPS learning models on student achievement, there is an influence of } \\
\text { motivation on student achievement, and there is no interaction between } \\
\text { learning models and motivation on student achievement. }\end{array}$} \\
\hline & \\
\hline Info & Abstrak \\
\hline $\begin{array}{l}\text { Sejarah Artikel } \\
\text { Diterima: } 25 \mathrm{Apr} \\
\text { Direvisi: } 20 \mathrm{Juni} \\
\text { Dipublikasi: } 30 \mathrm{~J}\end{array}$ & \multirow{2}{*}{$\begin{array}{l}\text { Penelitian ini bertujuan untuk mengetahui pengaruh model pembelajaran } \\
\text { NHT dan TPS terhadap prestasi belajar siswa, pengaruh motivasi terhadap } \\
\text { prestasi belajar siswa, dan interaksi antara model pembelajaran dengan } \\
\text { motivasi terhadap prestasi belajar siswa. Jenis penelitian ini adalah penelitian } \\
\text { eksperimen. Populasi dalam penelitian ini ialah seluruh siswa kelas VIIMTs. } \\
\text { NW Wanasaba yang berjumlah } 60 \text { orang yang terdiri dari } 3 \text { kelas yaitu : kelas } \\
\text { VIIA, VIIB dan VIIC. Sampel penelitian adalah kelas VIIA dan VIIB yang } \\
\text { diperoleh dengan cara Cluster Random Sampling. Teknik pengumpulan data } \\
\text { dilakukan dengan menggunakan metode tes obyektif pilihan ganda. Uji } \\
\text { prasyarat yang digunakan yaitu uji normalitas dan uji homogen, dimana uji } \\
\text { normalitas dengan menggunakan chi-kuadrat dan uji homogenitas dengan } \\
\text { menggunakan uji Bartlet. Sedangkan teknik analisa data yang digunakan } \\
\text { untuk menguji hipotesis ialah uji Anava Dua Jalan (two way anava) dan } \\
\text { menggunakan uji scheff untuk uji lanjut anava. Hasil analisis dalam penelitian } \\
\text { ini menunjukkan bahwa ada pengaruh model pembelajaran NHT dan TPS } \\
\text { terhadap prestasi belajar siswa, ada pengaruh motivasi terhadap prestasi } \\
\text { belajar siswa, dan tidak ada interaksi antara model pembelajaran dengan } \\
\text { motivasi terhadap prestasi belajar siswa }\end{array}$} \\
\hline & \\
\hline
\end{tabular}

Sitasi: Zahara, L., Syahidi, K., Fartina, F., Novianti, B.A., Suriani, S. (2021). Pembelajaran Kooperatif Tipe Numbered Head Together dan Think Pair Share Ditinjau dari Motivasi. Kappa Journal, 5(1) 142-148. 


\section{PENDAHULUAN}

Pendidikan di Indonesia berupaya untuk menciptakan bangsa yang cakap, beriman, bertaqwa kepada Tuhan serta memilki pengetahuan yang baik dan wawasan kebangsaan (Sujana 2019). Dengan demikian pendidikan sangan berperan penting dalam membentuk kakter seseorang. Adapun sistem pembelajaran terdiri dari beberapa komponen yang saling berinteraksi satu sama lain, yaitu: guru, siswa, tujuan, materi, media, metode, dan evaluasi. Pembelajaran tidak akan dapat terlaksana dengan baik tanpa adanya interaksi antara komponen pembelajaran, maka diantara jenis komponen pembelajaran tersebut haruslah saling bekerja sama sehingga tercipta pembelajaran yang efisien (Pane and Darwis Dasopang 2017). Untuk meningkatkan interaksi antar komponen pembelajaran diperlukan suatu metode pembelajaran inovatif. Salah satu bentuk pembelajaran inovatif adalah pembelajaran kooperatif. Pembelajaran kooperatif adalah sistem pengajaran yang memberikan kesempatan kepada anak didik untuk bekerjasama dengan sesama siswa dalam tugas - tugas yang terstruktur (Eviliyanida 2011).

NHT dan TPS termasuk kedalam bagian dari model pebelajaran kooperatif. Pembelajaran kooperatif tipe NHT merupakan salah satu tipe pembelajaran kooperatif yang menekankan pada struktur khusus yang dirancang untuk mempengaruhi pola interaksi siswa dan memiliki tujuan untuk meningkatkan penguasaan akademik (Sulipan 2011). TPS (Think-Pair-Share) atau (Berfikir-Berpasangan-Berbagi) merupakan jenis pembelajaran kooperatif yang dirancang untuk member waktu pada siswa untuk berpikir dan merespon untuk saling membantu. Keunggulannya adalah optimalisasi partisipasi siswa(Yeni, S. 2010). Berdasarkan pengertian dari pembelajaran kooperatif maka pembelajaran ditekankan pada adanya interaksi antar siswa dalam kelompok. Dengan demikian interaksi mempengaruhi keberhasilan siswa dalam menguasai materi.

Salah satu factor yang mempengaruhi prestasi belajar siswa adalah motivasi belajar. Kata motivasi diambil dari bahasa latin, movere yang artinya dorongan dari diri sendiri untuk mencapai sesuatu yang dikehendaki. Motivasi belajar artinya dorongan dari diri siswa untuk mencapai tujuan belajar, misalnya pemahaman materi atau pengembangan belajar (Wiandari 2021). Berdasarkan penelitian yang dilakukan oleh Ika Rahmawati dengan judul Model pembelajaran kooperatif dengan numbered heads Together (NHT) dan think pair share (TPS) ditinjau dari Motivasi berprestasi dan gaya belajar siswa, hasil penelitian menunjukkan ada pengaruh model pembelajaran kooperatif dengan prestasi dan ada pengaruh motivasi terhadap prestasi. Dengan demikian melalui peneliti ini, peneliti ingin mengetahui lebih jauh hubungan antara model pembelajaran kooperatif tipe NHT dan TPS ditinjau dari motivasi belajar Siswa kelas VII MTS NW Wanasaba pada Materi Kalor.

\section{METODE}

Penelitian ini termasuk jenis penelitian eksperimen. Kedua kelompok tersebut diberi perlakuan yang berbeda, kelompok eksperimen akan diberikan perlakuan dengan pembelajaran kooperatif dengan tipe Think Pair Share (TPS), sedangkan kelompok Kontrol akan diberi perlakuan dengan pembelajaran kooperatif dengan tipe Numbered Head Together (NHT). Kedua kelompok tersebut diasumsikan homogen dalam segala segi yang relevan dengan penyebaran normal dan hanya berbeda dalam penggunaan media pembelajaran. Waktu yang diperlukan dalam menyelesaikan proses belajar mengajar diasumsikan sama. Hasil dari kedua kelompok tersebut kemudian dibandingkan untuk mengetahui mana yang lebih baik dan tepat dari kedua model pembelajaran tersebut untuk 
menyampaikan materi tentang kalor. Dalam penelitian ini desain penelitian yang digunakan adalahPosttest-Only Control Design, sedangkan rancangan Analisis penelitiannya menggunakan rancangan Analisis Variansi Dua Jalur (Two-Ways-Anova) .

Tabel 1.Rancangan Analisis Variansi Dua Jalur

\begin{tabular}{cccc}
\hline & $\mathrm{A}$ & $\mathrm{A}_{1}$ & $\mathrm{~A}_{2}$ \\
\hline $\mathrm{B}$ & & A1B1 & A1B2 \\
\hline $\mathrm{B}_{1}$ & A1B2 & A2B2 \\
\hline
\end{tabular}

Keterangan :

A $=$ Model pembelajaran

$\mathrm{A}_{1}=$ Menggunakan model pembelajaran TPS

$\mathrm{A}_{2}=$ Menggunakan model pembelajaran NHT

$\mathrm{B}=$ Motivasi

$\mathrm{B}_{1}=$ Motivasi tinggi

$\mathrm{B}_{2}=$ Motivasi Rendah

Uji hipotesis yang digunakan adalah analisis variansi (anava) dua jalan dengan sel tak sama. Tujuan dari analisis ini untuk menguji signifikansi pengaruh dua variabel bebas terhadap satu variabel terikat yang disertai dengan satu variabel moderator juga. Uji hipotesis dilakukan untuk mengetahui apakah hipotesis yang telah diajukan diterima atau ditolak.

\section{HASIL DAN PEMBAHASAN}

Data prestasi belajar didapatkan dari hasil tes prestasi belajar pada materi kalor. Deskripsi data nilai prestasi belajar siswa pada aspek kognitif dari masing-masing kelas disajikan dalam tabel 2 berikut:

Tabel 2. Deskripsi Data Nilai Prestasi Belajar Siswa Pada Aspek Kognitif

\begin{tabular}{ccccccc}
\hline Kelas & $\begin{array}{c}\text { Jumla } \\
\mathrm{h} \\
\text { Siswa }\end{array}$ & $\begin{array}{c}\text { Total } \\
\text { Skor } \\
\left(\sum X\right)\end{array}$ & $\begin{array}{c}\text { Nilai } \\
\text { tertingg } \\
\mathrm{i}\end{array}$ & $\begin{array}{c}\text { Nilai } \\
\text { terenda } \\
\mathrm{h}\end{array}$ & $\begin{array}{c}\text { Mea } \\
\mathrm{n}( \\
X)\end{array}$ & $\begin{array}{c}\text { Standar } \\
\text { Deviasi } \\
(\mathrm{SD})\end{array}$ \\
\hline NHT & 20 & 1195 & 80 & 45 & 58,75 & 10,38 \\
\hline TPS & 20 & 1276 & 90 & 60 & 72,4 & 9,59 \\
\hline
\end{tabular}

Pada tabel $4.1 \mathrm{di}$ atas terlihat untuk kelas NHT nilai tertinggi pada prestasi belajar adalah 80 dan nilai terendah 45 dengan rata-rata 58,75 serta standar deviasi 10,38. Sementara untuk kelas TPS nilai tertinggi pada prestasi belajar adalah 90, nilai terendah 60 dengan rata-rata 72,4 serta standar deviasi 9,59. Berdasarkan data yang tercantum pada tabel tersebut nilai rata-rata prestasi belajar pada kelas NHT lebih rendah dibandingakan dengan nilai rata- rata prestasi belajar siswa dengan kelas TPS.

Data motivasi belajar siswa diperoleh dari angket motivasi yang diberikan kepada siswa atau responden. Pembagian kategori motivasi belajar siswa berdasarkan pada nilai rata-rata dari masing-masing kelas. Motivasi belajar tinggi apabila skor hasil angket motivasi $\geq$ nilai rata-rata hasil motivasi secara keseluruhan dan motivasi belajar rendah apabila skor hasil angket motivasi $\leq$ nilai rata-rata hasil motivasi secara keseluruhan. Deskripsi data motivasi belajar siswa dapat dilihat pada tabel 3. 
Tabel 4. Deskripsi Data Motivasi Siswa

\begin{tabular}{lcccc}
\hline Kelompok & $\begin{array}{c}\text { Jumlah } \\
\text { Siswa }\end{array}$ & $\begin{array}{c}\text { Total Skor } \\
\left(\sum X\right)\end{array}$ & $\begin{array}{c}\text { Standar } \\
\text { Deviasi (SD) }\end{array}$ \\
\hline Motivasi tinggi & 23 & 1590 & 69,02 & 12,49 \\
\hline Motivasi rendah & 17 & 1060 & 59,47 & 8,903 \\
\hline
\end{tabular}

Uji hipotesis yang digunakan dalam penelitian ini adalah anava dua jalan dengan sel tak sama. Sebelum melakukan uji hipotesis terlebih dahulu dilakukan uji prasyarat analisis yaitu uji normalitas data dan uji homogenitas data.

Tabel 5. Rekapitulasi Uji Normalitas kelas dan kelompok

\begin{tabular}{|c|c|c|c|c|}
\hline $\begin{array}{l}\text { Kelas dan } \\
\text { Kelompok }\end{array}$ & $\begin{array}{c}\text { Jumlah } \\
\text { Responden }\end{array}$ & $\begin{array}{c}\square \\
2 \text { hitun } \\
g\end{array}$ & $\begin{array}{c}2 \\
\text { tabel }\end{array}$ & Keputusan Uji \\
\hline Kelas NHT & 20 & 2,17 & 11.070 & Terdistribusi Normal \\
\hline Kelas TPS & 20 & 6,69 & 11.070 & Terdistribusi Normal \\
\hline Motivasi Tinggi & 23 & 2,77 & 11.070 & Terdistribusi Normal \\
\hline Motivasi Rendah & 17 & 2,88 & 11.070 & Terdistribusi Normal \\
\hline SEL A1B1 & 11 & 2,24 & 9,488 & Terdistribusi Normal \\
\hline SEL A1B2 & 9 & 0,73 & 7,815 & Terdistribusi Normal \\
\hline SEL A2B1 & 12 & 6,48 & 9,488 & Terdistribusi Normal \\
\hline SEL A2B2 & 8 & 3,56 & 7,815 & Terdistribusi Normal \\
\hline
\end{tabular}

Tabel 6. Rekapitulasi Uji Homogenitas Data Hasil Belajar Siswa

\begin{tabular}{clccc}
\hline No & Komponen Data & $q^{2}$ tabel & $\square^{2}$ hitung & $\begin{array}{c}\text { Keputusa } \\
\mathbf{n}\end{array}$ \\
\hline 1 & Kelas NHT & 3,841 & 0,47 & Homogen \\
\hline 2 & Kelas TPS & 3,841 & 0,59 & Homogen \\
\hline 3 & Motivasi Tinggi & 3,841 & 0,64 & Homogen \\
\hline 4 & Motivasi Rendah & 3,841 & 0,41 & Homogen \\
\hline 5 & Keseluruhan & 7,815 & 1,95 & Homogen \\
\hline
\end{tabular}

Uji hipotesis yang digunakan adalah analisis variansi (anava) dua jalan dengan sel tak sama. Tujuan dari analisis ini untuk menguji signifikansi pengaruh dua variabel bebas terhadap satu variabel terikat yang disertai dengan satu variabel moderator juga. Uji hipotesis dilakukan untuk mengetahui apakah hipotesis yang telah diajukan diterima atau ditolak. Adapun deskripsi data prestasi belajar siswa dengan menggunakan metode pembelajaran Numbered Head Together (NHT) dan Think Pair Share (TPS) ditinjau dari motivasi berprestasi siswa disajikan dalam rangkuman tabel berikut. 
Tabel 7. Data Prestasi Belajar Siswa ditinjau dari Motivasi Berprestasi Siswa

\begin{tabular}{|c|c|c|c|c|c|c|c|}
\hline \multirow[b]{2}{*}{ B } & \multirow[t]{2}{*}{$\mathbf{A}$} & \multicolumn{4}{|c|}{$\begin{array}{c}\text { A } \\
\text { Metod } \\
\mathbf{e} \\
\end{array}$} & & \multirow[t]{2}{*}{ Total } \\
\hline & & & $\begin{array}{c}\text { A1 } \\
\text { NHT }\end{array}$ & & $\begin{array}{l}\text { A2 } \\
\text { TPS }\end{array}$ & & \\
\hline \multirow{14}{*}{$\begin{array}{c}\text { B } \\
\text { Motivas } \\
\text { i }\end{array}$} & \multirow{7}{*}{$\begin{array}{c}\text { B1 } \\
\text { Tinggi }\end{array}$} & $\mathrm{n}$ & 11 & $\mathrm{n}$ & 12 & $\mathrm{n}$ & 23 \\
\hline & & $\sum \mathrm{X}$ & 690 & $\sum \mathrm{X}$ & 900 & $\sum \mathrm{X}$ & 1590 \\
\hline & & $\sum \mathrm{X}^{2}$ & 44650 & $\sum X^{2}$ & 68450 & $\sum \mathrm{X}^{2}$ & 113100 \\
\hline & & & 62,32 & & 75,2 & & 69,02 \\
\hline & & $\bar{X}$ & & $\bar{X}$ & & $\bar{X}$ & \\
\hline & & $S$ & 11,36 & $S$ & 9,12 & $S$ & 12,49 \\
\hline & & $S^{2}$ & 129,05 & $S^{2}$ & 83,17 & $S^{2}$ & 156,00 \\
\hline & \multirow{7}{*}{$\begin{array}{c}\text { B2 } \\
\text { Renda } \\
\mathbf{h}\end{array}$} & $\mathrm{n}$ & 9 & $\mathrm{n}$ & 8 & $\mathrm{n}$ & 17 \\
\hline & & $\sum X$ & 505 & $\sum \mathrm{X}$ & 555 & $\sum \mathrm{X}$ & 1060 \\
\hline & & $\sum \mathrm{X}^{2}$ & 29075 & $\sum X^{2}$ & 38825 & $\sum X^{2}$ & 67900 \\
\hline & & & 55,9 & & 68,5 & & 59,47 \\
\hline & & $\bar{X}$ & & $\bar{X}$ & & $\bar{X}$ & \\
\hline & & $S$ & 9,04 & $S$ & 7,17 & $S$ & 8,903 \\
\hline & & $S^{2}$ & 81,72 & $S^{2}$ & 51,41 & $S^{2}$ & 79,26 \\
\hline
\end{tabular}

Berdasarkan hasil perhitungan anava dua jalan didapatkan hasil perhitungan yang disajikan dalam bentuk tabel sebagai berikut.

Tabel 8. Ringkasan Anava Dua Jalur

\begin{tabular}{|c|c|c|c|c|c|}
\hline $\begin{array}{l}\text { Sumber } \\
\text { Varians }\end{array}$ & $\begin{array}{c}\text { Derajat } \\
\text { Kebebasan } \\
(\mathbf{d K})\end{array}$ & $\begin{array}{c}\text { Jumlah } \\
\text { Kuadrat } \\
\text { (JK) }\end{array}$ & $\begin{array}{c}\text { Kuadrat } \\
\text { Rerata } \\
\text { (KR) }\end{array}$ & $\begin{array}{c}\text { Fhitu } \\
\text { ng }\end{array}$ & F tabel \\
\hline antar group (A) & 1 & 1690 & 1690 & 17,99 & \multirow{5}{*}{$\begin{array}{l}\alpha 5 \%= \\
4,11\end{array}$} \\
\hline antar group (B) & 1 & 449,02 & 449,02 & 4,78 & \\
\hline dalam group (AB) & 1 & $-80,465$ & $-80,465$ & 0,85 & \\
\hline dalam group (D) & 36 & 3378,94 & 93,9 & & \\
\hline Total & 39 & 5437,5 & & & \\
\hline
\end{tabular}

Keputusan Uji:

$F_{\text {A hitung }}>F_{\text {A tabel }}$ atau $17,99>4,11$ maka $\mathrm{H}_{\mathrm{oA}}$ ditolak

$F_{B \text { hitung }}>\mathrm{F}_{\text {Btabel }}$ atau 4,78>4,11maka $\mathrm{H}_{\mathrm{oB}}$ ditolak

$F_{A B \text { hitung }}<\mathrm{F}_{A B t a b e l}$ atau $0,85>4,11$ maka $\mathrm{H}_{\mathrm{OAB}}$ diterima

Hipotesis 1

Didapatkan hasil Keputusan: $F_{A}$ hitung $>F_{A}$ tabel atau 17,99>4,11 maka $\mathrm{H}_{\mathrm{oA}}$ ditolak. Dengan demikian ada pengaruh Metode Pembelajaran kooperatif terhadap prestasi belajar. Setelah dilakukan uji lanjut didapatkan hasil Keputusan : 19,84>4,11 atau $t_{\text {hitung }}>t_{\text {tabel }}$, maka 
Ho ditolak. Kesimpulan hasil belajar siswa yang diajarkan dengan pembelajaran kooperatif tipe TPS lebih tinggi dari hasil belajar siswa yang diajarkan dengan pembelajaran kooperatif tipe NHT. Hasil yang diperoleh sesuai dengan penelitian Widyiastuti yaitu ada pengaruh pembelajaran model TPS dan NHT pada prestasi belajar kognitif, afektif, dan kognitif siswa (Widiyastuti 2013), yaitu TPS menghasilkan prestasi yang lebih baik dari NHT. Hal ini dikarenakan pada tahapan pembelajaran TPS akan memungkinkan siswa untuk saling bertukar informasi dan kerjasama yangtercipta dapat meningkatkan prestasi belajar siswa. Hasil yang sama diperoleh M Farid Nasrulloh, yaitu pembelajaran kooperatif tipe TPS efektif ditinjau dari prestasi belajar matematika (Nasrulloh 2017). Penelitian lain yang dilakukan oleh menunjukkan bahwa terdapat pengaruh prestasi belajar dengan model NHT dan TPS(MarantikaLia Kristyasari and Budi Hastuti 2015).

\section{Hipotesis Kedua}

Didapatkan hasil Keputusan: $F_{B \text { hitung }}>\mathrm{F}_{\text {Btabel }}$ atau 4,78>4,11maka $\mathrm{H}_{\mathrm{oB}}$ ditolak, dengan demikian ada pengaruh motivasi terhadap prestasi belajar. Setelah dilakukan ujilanjut didapatkan : 5,27 $>4,11$ atau $t_{\text {hitung }}>\mathrm{t}_{\text {tabel }}$, maka Ho ditolak sehingga dapat disimpulkan hasil belajar siswa yang memiliki motivasi tinggi lebih tinggi dari hasil belajar siswa yang memiliki motivasi rendah. Dalam pembelajaran di kelas, dijumpai siswa yang memiliki motivasi belajar tinggi lebih mudah untuk memahami materi pelajaran dan lebih mudah dalam memecahkan setiap masalah yang diberikan oleh guru dibandingkan dengan siswa yang memiliki motivasi belajar rendah. Dimana berdasarkan teori dengan adanya motivasi yang tinggi maka siswa akan merasa terpacu untuk belajar dan mendapatkan nilai yang tinggi, itu semua merupakan efek dari rasa ingin tahu mereka yang tinggi dan sebaliknya.

\section{Hipotesis Ketiga}

Didapatkan keputusan: $F_{A B}$ hitung $<\mathrm{F}_{A B t a b e l}$ atau 0,85> 4,11 maka $\mathrm{H}_{\mathrm{OAB}}$ diterima. Hal ini menyatakan bahwa tidak terdapat interaksi antara pembelajarn kooperatif dan motivasi belajar terhadap hasil belajar siswa. Artinya interaksi antara metode dengan motivasi tidak berpengaruh terhadap prestasi belajar. Kedua metode yang digunakan baik untuk motivasi tinggi dan rendah memiliki pengaruh yang sama terhadap prestasi belajar siswa.

\section{KESIMPULAN}

Berdasarkan uji anava terhadap hipotesis yang di ajukan, maka kesimpulannya adalah: Ada perbedaan yang signifikan antara pembelajaran kooperatif dengan menggunakan metode NHT dan TPS terhadap prestasi belajar siswa khususnya pada materi kalor. Pembelajaran dengan menggunakan model TPS lebih baik daripada pembelajaran dengan model NHT terhadap prestasi; Ada perbedaan yang signifikan antara siswa yang memiliki motivasi tinggi dan siswa yang memiliki motivasi rendah dalam pembelajaran, khususnya pada materi kalor; Tidak ada interaksi pembelajaran kooperatif tipe NHT dan TPS serta motivasi belajar terhadap prestasi belajar siswa pada materi kalor. Pembelajaran dengan motivasi tinggi lebih baik daripada pembelajaran dengan motivasi rendah terhadap prestasi

\section{SARAN}

Diharapkan untuk penelitian- penelitian selanjutnya apabila menggunakan model pembelajaran yang sama akan mendapatkan nilai yang lebih baik lagi dan para guru di Indonesia lebih berani mengembangkan inovasi dan kreasinya dalam menggunakan model pembelajaran yang tepat dalam pembelajaran fisika 


\section{UCAPAN TERIMA KASIH}

Ucapan terima kasih diucapkan semua pihak yang terlibat dalam penelitian ini khususnya Tim Dosen Prodi Pendidikan Fisika, FMIPA Universitas Hamzanwadi.

\section{DAFTAR PUSTAKA}

Eviliyanida. 2011. "Model Pembelajaran Kooperatif." Visipena Journal.

MarantikaLia Kristyasari, M. Masykuri and Budi Hastuti. 2015. "Pengaruh Model Pembelajaran Kooperatif Tipe NHT Dan TPS Terhadap Prestasi Belajar Ditinjau Dari Kemampuan Matemaitika Pada Matematika .” 2015 4(3).

Nasrulloh, Farid. 2017. "Keefektifan Model Kooperatif Tipe TPS dan NHT ditinjau dari Prestasi Belajar Matematika Siswa Kelas XI." Eduscope: Jurnal Pendidikan, Pembelajaran, Dan Teknologi 3(1):176-89.

Pane, Aprida and Muhammad Darwis Dasopang. 2017. "Belajar Dan Pembelajaran." FITRAH:Jurnal Kajian Ilmu-Ilmu Keislaman 3(2):333.

Sujana, I. Wayan Cong. 2019. "Fungsi Dan Tujuan Pendidikan Indonesia." Adi Widya: Jurnal Pendidikan Dasar.

Sulipan. 2011. "Model Pembelajaran Kooperatif Numbered Head Together (NHT) Pengembangan Pendidikan Dan Sumber Daya Manusia." Retrieved April 18, 2021 (https://sulipan.wordpress.com/2011/05/16/model-pembelajaran-kooperatif-numberedhead-together-nht/).

Wiandari, Eka. 2021. "Motivasi Belajar Siswa: Jenis \& Cara Meningkatkannya| Quipper Blog.” Retrieved April 18, 2021 (https://www.quipper.com/id/blog/info-guru/motivasibelajar-siswa/).

Widiyastuti, Sri. 2013. "Pembelajaran Fisika Model Kooperatif Think Pair Share (TPS) Dan Numbered Heads Together (NHT) Ditinjau Dari Interaksi Sosial Dan Sikap Ilmiah.”

Yeni and Siti. 2010. "Model Pembelajaran Kooperatif Tipe Think Pair Share Fisika SMA Online." $\quad$ Retrieved April 18, $2021 \quad$ (http://fisikasmaonline.blogspot.com/2010/12/model-pembelajaran-kooperatif-tipe.html). 